\title{
Cardiac involvement and clinical follow up of patients with hereditary transthyretin related amyloidosis associated with Glu89Gln mutation
}

\author{
Mariana Gospodinova ${ }^{*}$, Stayko Sarafov ${ }^{2}$, Velina Guergueltcheva ${ }^{3}$, Andrey Kirov ${ }^{4}$, Teodora Chamova², \\ Albena Todorova ${ }^{4}$, Ivailo Tournev², Stefan Denchev ${ }^{1}$ \\ From First European Congress on Hereditary ATTR amyloidosis \\ Paris, France. 2-3 November 2015
}

\section{Background}

Cardiac involvement is common in hereditary transthyretin - related amyloidosis (ATTR), but there is a significant phenotypic heterogeneity depending on the mutation.

\section{Patients and methods}

We evaluated forty consecutive ATTR patients with Glu89Gln mutation, focusing on cardiac involvement - 18 male, 22 female at a mean age of $57.6 \pm 6,7$ years. A clinical examination, 12-channel ECG, conventional 2D, Doppler and tissue Doppler echocardiography were performed. The patients were followed for 36 months in the range from 2 to 78 months.

\section{Results}

Median age of symptoms development was $52,3 \pm 6,4$ years. Cardiac onset was found in $5(12,5 \%)$ patients. Cardiomyopathy and peripheral polyneuropathy were evident at diagnosis in all patients. Echocardiography revealed a significant increase in wall thickness of both left and right ventricles (septum - 18,6 $\pm 3,4 \mathrm{~mm}$; posterior wall $-17,5 \pm 2,5 \mathrm{~mm}$; RV free wall $-8,4 \pm 2,0$ $\mathrm{mm})$. Varying degrees of LV diastolic dysfunction were found - Grade 1 in $11(27,5 \%)$ patients, Grade 2 in 12 (30\%) and Grade 3 in $17(42,5 \%)$ patients. A reduced LV ejection fraction was found in $9(22,5 \%)$ patients. A common finding were significantly reduced mitral annular systolic velocities (s'septum-5,4 $\pm 2,0 \mathrm{~cm} / \mathrm{s}, \mathrm{s}$ lat. $-5,7 \pm 1,9 \mathrm{~cm} / \mathrm{s}$ ), registered in all the evaluated patients, pointing to an impaired LV longitudinal

${ }^{1}$ Medical Institute of Ministry of Interior, Clinic of Cardiology, 1606, Sofia, Bulgaria

Full list of author information is available at the end of the article systolic function. The systolic myocardial velocities of the tricuspid annulus and TAPSE values were reduced respectively $6,9 \pm 2,1 \mathrm{~cm} / \mathrm{s}$ and $12,8 \pm 3 \mathrm{~mm}$ in 14 of the patients $(35 \%)$. Pericardial effusion was found in $13(32,5 \%)$ patients.

Pathological ECG was present in $35(87,5 \%)$ of the evaluated patients. Atrial fibrillation was registered in $4(10 \%)$ patients, A-V block first degree in $8(20 \%)$, low voltage in $15(37,5 \%)$, left bundle branch block in $3(7,5 \%)$, left anterior fascicular block in $9(22,5 \%)$, pathological Q wave in 14 (35\%), right bundle branch block in $2(5 \%)$, and pace-maker rhythm in $2(5 \%)$. Rhythm and conduction disturbances on ECG were found in 24 patients (60\%).

The following events occurred during the follow-up period: two deaths $(5,4 \%)$ (one patient due to ischemic stroke; and another due to heart failure). Two other patients suffered from ischemic strokes. 24-hour Holter ECG revealed short periods of atrial fibrillation and an oral anticoagulant was initiated. A sinus pause $>3 \mathrm{~s}$ was observed in one of the patients and a permanent pacemaker was implanted. Four new cases $(10 \%)$ with symptomatic heart failure, requiring diuretic treatment were observed. In 15 patients a worsening of the symptoms from the peripheral neuropathy were found.

\section{Conclusion}

Our study confirms that ATTR associated with the Glu89Gln mutation has a mixed phenotype - neurological and cardiac and an unfavorable prognosis. Our findings imply that patients and carriers of Glu89Gln require close multidisciplinary (both cardiological and neurological) follow-up in order to initiate treatment in time. 


\section{Authors' details}

'Medical Institute of Ministry of Interior, Clinic of Cardiology, 1606, Sofia,

Bulgaria. ${ }^{2}$ University Hospital Alexandrovska, Clinic of Neurology, 1431, Sofia,

Bulgaria. ${ }^{3}$ University Hospital Sofiamed, Neurology Department, 1528, Sofia,

Bulgaria. ${ }^{4}$ Genetic lab, Genika, 1113, Sofia, Bulgaria.

Published: 2 November 2015

doi:10.1186/1750-1172-10-S1-P54

Cite this article as: Gospodinova et al:: Cardiac involvement and clinical follow up of patients with hereditary transthyretin related amyloidosis associated with Glu89GIn mutation. Orphanet Journal of Rare Diseases 2015 10(Suppl 1):P54.

Submit your next manuscript to BioMed Central and take full advantage of:

- Convenient online submission

- Thorough peer review

- No space constraints or color figure charges

- Immediate publication on acceptance

- Inclusion in PubMed, CAS, Scopus and Google Scholar

- Research which is freely available for redistribution

Submit your manuscript at www.biomedcentral.com/submit 